\title{
legelivet
}

På disse sidene i Tidsskriftet - legelivet - finner du stoff om legers liv.

Her er det presentasjon av arbeidssteder, nyhetssaker, nye doktorgrader,

nye spesialister og minneord. Alt samlet på ett sted - så du kan følge enda bedre med.

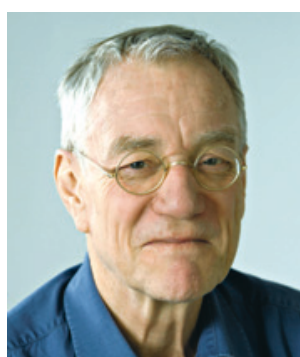

Olaf Gjerløw Aasland. Foto: Einar Nilsen

«De etablerte helseprofesjonene blir utfordret til å komme ut av sine siloer for å bygge fremtidens systembaserte helsetjeneste»

\section{Er dagens leger dinosaurer?}

Vi utdanner fremdeles helsepersonell for gårsdagens pasienter.

En stor internasjonal ekspertgruppe under ledelse av Julio Frenck, tidligere helseminister i Mexico og nå professor og dekanus ved Harvard School of Public Health publiserte i 2010 en omfattende artikkel om hvordan dagens utdanningsløp for leger og andre helseprofesjoner ikke vil kunne møte fremtidens globale helseutfordringer, verken i forhold til kompetanse eller fordeling (1).

Innledningsvis pekes det på at dagens helseprofesjonsutdanninger på grunn av sin fragmenterte, utdaterte og statiske oppbygning ikke har holdt tritt med utviklingen i befolkningens behov for helsehjelp. Dette skyldes bl.a. dårlig teamarbeid, vedvarende kjønnsforskjeller, tekniske løsninger som ikke settes inn i en større sammenheng, manglende regelmessig og systematisk oppfølging av pasientene, for stor vekt på sykehusmedisin i forhold til primærhelsetjeneste, uhensiktsmessige kvantitative og kvalitative forskjeller på helseprofesjonsmarkedet samt manglende kvalitetsledelse. Verken i rike eller fattige land gir økte ressurser til helseprofesjonsutdanning synlige resultater i form av bedre helse i befolkningen.

Forfatterne foreslår en modell for å forstå hvorfor vi har havnet der vi er i dag. De ten- ker seg tre generasjoner av profesjonsutdanninger i vår del av verden. Den første, som startet for vel hundre år siden, introduserte et forskningsbasert curriculum med utgangspunkt i universitetene - informative learning. Med den andre, som startet etter den annen verdenskrig-formative learning-ble utdanningen i økende grad knyttet opp mot problembasert læring også utenfor universiteter og sykehus. Den tredje, systembaserte generasjonen - transformative learning har bare så vidt startet. Det finnes fremdeles mange første- og enda flere annengenerasjons utdanningssteder.

Artikkelen munner ut i ti reformforslag, der bl.a. de etablerte helseprofesjonene blir utfordret til å komme ut av sine siloer for å bygge fremtidens systembaserte helsetjeneste, der etterspørselen (pasientene) og tilbudet (profesjonsutdanningene) er bedre tilpasset hverandre.

\section{Olaf Gjerløw Aasland \\ olaf.aasland@legeforeningen.no}

\section{Litteratur}

1. Frenk J, Chen L, Bhutta ZA et al. Health professionals for a new century: transforming education to strengthen health systems in an interdependent world. Lancet 2010; 376: 1923-58. 